Copyright (C) 2021 University of Bucharest Printed in Romania. All rights reserved

ISSN print: $1224-5984$

ISSN online: $2248-3942$
Rom Biotechnol Lett. 2021; 26(2): 2448-2454

doi: $10.25083 / \mathrm{rbl} / 26.2 / 2448.2458$

Received for publication, March, 30, 2019

Accepted, September, 24, 2020

Original paper

\title{
Benefits of understanding the enzymatic activities in saline Lake Letea in the Danube Delta
}

\section{ANCA IOANA LUCACI ${ }^{\bowtie 1}$, SIMONA NEAGU ${ }^{1}$, ROXANA COJOC ${ }^{1}$, ROBERT RUGINESCU ${ }^{1}$, IOAN ARDELEAN ${ }^{1}$, MĂDĂLIN ENACHE ${ }^{1}$}

${ }^{1}$ Institute of Biology Bucharest of the Romanian Academy, Bucharest, Romania

\begin{abstract}
The purpose of this paper was to isolate halophiles from Letea saline lake and to performed a screening for industrially relevant extracellular enzymes. The investigations were conducted from October 2016 until May 2018. After a random selection of colonies that grew on the medium culture, 82 isolates were investigated. Based on their salt requirements and tolerance, it was remarked the presence of isolates belonging to halotolerant and moderate halophilic bacteria. Morphological and biochemical tests were used to characterize them. The ability of the tested isolates to produce extracellular enzymes was evaluated on the culture medium with salinity varying between $0-4 \mathrm{M}$ and supplemented with a specific substrate. The highest hydrolytic activities were recorded for casein at $0 \mathrm{M} \mathrm{NaCl}, 1 \mathrm{M} \mathrm{NaCl}, 2 \mathrm{M} \mathrm{NaCl}$, and Tween 80 and inulin at $0 \mathrm{M} \mathrm{NaCl}, 1 \mathrm{M}$ $\mathrm{NaCl}, 2 \mathrm{M} \mathrm{NaCl}$, and $3 \mathrm{M} \mathrm{NaCl}$.
\end{abstract}

Keywords Hydrolytic enzymes, halophilic microorganism, Letea salt lake, Danube Delta.

To cite this article: LUCACI AI, NEAGU S, COJOC R, RUGINESCU R, ARDELEAN I, ENACHE M. Benefits of understanding the enzymatic activities in saline Lake Letea in the Danube Delta. Rom Biotechnol Lett. 2021; 26(2): 2448-2454. DOI: $10.25083 / \mathrm{rbl} / 26.2 / 2448.2454$

*Corresponding author: ANCA IOANA LUCACI, Institute of Biology Bucharest of the Romanian Academy, 296 Splaiul Independentei, 060031 Bucharest, P.O., Box 56-53, Romania

E-mail: ioana.lucaci@ibiol.ro 


\section{Introduction}

Saline soda lakes are widely distributed around the world, especially in arid or semiarid subtropical regions (FOTI \& al [5]). These types of ecosystems are inhabited by microorganisms with optimal growth at $\mathrm{pH} 9-10$. At around neutral $\mathrm{pH}$, their growth is weak or absent. In Lake Magadi and Lake Natron, 'haloalkaliphiles' need an 'additional 1.5-2M NaCl for optimum growth' (GRANT \& JONES [6]).

Over the years, soda lakes have attracted researchers' interest. Isachenko carried out morphological studies in 1931-1933, on lakes of the Kulunda Steppe region of Siberia (GRANT \& JONES [6]).

The first detailed microbiological analyses were made on African lakes, and then the studieswere focused on other sites, such as the Kulunda Steppe region (Russia), the Inner Mongolian lakes (China), Lonar Lake (India), and Mono Lake (California) (FOTI \& al [5]).

General reviews about saline soda lake microbiology have been written by Grant and Tindall (1986), Grant (1992, 2003, 2006), Grant and Mwatha (1989), Grant and Jones (2000), Jones and Grant (2000) and Jones et al. (1994, 1998a, b), Sorokin et al (2014a) (GRANT \& JONES [6]).

Due to their capacity to thrive under harsh conditions, microbial communities from soda lakes were studied for the biotechnological use of enzymes and metabolites. For example, proteases are used in laundry detergents and pharmaceuticals, in the manufacture of leather, waste management, and food processing (YIN \& al [20]). Xylanases are used in the pulp paper industry and to manufacture the starch used in foodstuffs, chemicals, cosmetics, and pharmaceuticals (GRANT \& al [8]; HORIKOSHI [10]). Halophilic amylases, due to their high stability, are used for the treatment of wastewater containing high salt and starch residues (MARGESIN \& SCHINNER [14]). Cellulases are used in the textile, laundry, and food industries (YIN \& al [20]).

This paperdescribes the screening of halophilic bacteria from Letea saline Lake in the Danube Delta, Romania for the production of different extracellular hydrolytic enzymes. The results provide information about their potential utilization in industrial processes and based on our knowledge, this is the first investigation in this matter for the ecosystem Letea salt lake inner Danube Delta.

\section{Materials and Methods}

Samples of water and sediment were collected in sterile bottles from three sampling points (L1, L2 and L3), over three years (October 2016 - May 2018). They were transported at $4{ }^{\circ} \mathrm{C}$ to the laboratory for further tests (LUCACI \& al [13]).

The halophilic bacterial strains were isolated and purified on solidified $\mathrm{MH}$ medium with $\mathrm{pH} 7.2$ and following composition $\left(\mathrm{g} \mathrm{L}^{-1}\right)$ : proteose peptone, 5; glucose, 1 ; yeast extract, $10 ; \mathrm{NaCl}, 100 ; \mathrm{MgCl}_{2} \times 6 \mathrm{H}_{2} \mathrm{O}, 7$;
$\mathrm{MgSO}_{4} \times 7 \mathrm{H}_{2} \mathrm{O}, 9.6 ; \mathrm{CaCl}_{2} \times 2 \mathrm{H}_{2} \mathrm{O}, 0.36 ; \mathrm{KCl}, 2 ; \mathrm{NaHCO}_{3}$, 0.06; NaBr, 0.026; agar, 20 (VENTOSA \& al. [19]).

\section{Biochemical tests}

Oxidase. Thistest was performed using $1 \% \mathrm{~N}$, $\mathrm{N}, \mathrm{N}^{\prime}, \mathrm{N}^{\prime}$-p-phenilendiamine according to the standard procedures (bioMarieux). If an immediate or within 30' color change was observed, the reaction was considered positive.

Catalase. This test was performed using hydrogen peroxide $\left(\mathrm{H}_{2} \mathrm{O}_{2}\right)$ as previously described by AZHAR \& al (2014). It was considered a positive test the presence of bubbles that appeared following contact of the strain with hydrogen peroxide.

\section{Salinity influence on halophilic bacterial growth}

To study the range of $\mathrm{NaCl}$ concentration which allows the growth of halophilic bacteria, fresh cultures were inoculated on nutrient agar plates containing between $0 \mathrm{M}$ and $4 \mathrm{M} \mathrm{NaCl}$. They were incubated at $37^{\circ} \mathrm{C}$ for 48 hours. Growth of the isolates was considered a positive reaction (HALDER \& al [9]).

\section{Screening of strains for extracellular hydrolytic activities}

To evaluate the extracellular hydrolytic activities, a basal solidified $\mathrm{MH}$ medium was used with the following composition $\left(\mathrm{g} \mathrm{L}^{-1}\right)$ : yeast extract $10, \mathrm{MgCl}_{2} \times 6 \mathrm{H}_{2} \mathrm{O} 7$, $\mathrm{MgSO}_{4} \times 7 \mathrm{H}_{2} \mathrm{O} 9.6, \mathrm{CaCl}_{2} \times 2 \mathrm{H}_{2} \mathrm{O} 0.36, \mathrm{KCl} 2, \mathrm{NaHCO}_{3}$ $0.06, \mathrm{NaBr} 0.026$, supplemented with the test substrate and $\mathrm{NaCl}$ at concentrations varying from $0 \mathrm{M}$ to $4 \mathrm{M}$ (COJOC \& al [3]).

The ability of the isolated bacteria to produce different extracellular hydrolytic enzymes (amylase, protease, inulinase, cellulase, lipase) was further investigated.

\section{Detection of amylase activity}

The ability of the strains to degrade the basal solidified MH medium supplemented with $2 \mathrm{~g} \mathrm{~L}^{-1}$ soluble starch was tested using the method of KUMAR \& al (2012). Enzymatic activity was observed through the presence of a clear zone around the culture spots (ROHBAN \& al [16]).

\section{Detection of protease activity}

Proteolytic activity was tested according to the protocol of ENACHE \& KAMEKURA (2010), using 1\% casein as substrate. Enzymatic activity was observed through clear zones and the appearance of a precipitation ring around the culture spots.

\section{Detection of inulinase production}

Inulinase production was detected using the $\mathrm{MH}$ medium with inulin as the only source of carbon. Bacterial growth indicates inulinase activity (BABAVALIAN \& al [2]).

\section{Detection of cellulase activity}

The ability of the strains to degrade the basal $\mathrm{MH}$ medium supplemented with carboxymethyl cellulose (CMC) was tested using the method of ROHBAN \& al (2009). The appearance of a clear zone around the culture spots indicated cellulase activity (ROHBAN \& al [16]). 


\section{Detection of lipase activity}

Lipase activity was performed according the method of KUMAR \& al (2012). Clear zones around the culture spots indicated lipase production.

\section{DNA extraction and 16S rRNA gene analysis}

For the DNA extraction from isolates, DNeasy Blood $\&$ Tissue Kitwas used and the manufacture's protocol was respected. PCR of 16S rRNA genes of the extracted DNA was performed. Universal primers for bacteria were used: 27F (AGAGTTTGATCCTGGCTCAG) and 1492R (GCTTACCTTGTTACGACTT). The PCR mix contained: GoTaq G2 Hot Start Green Master Mix2x $(12.5 \mu \mathrm{l}), 1 \mu \mathrm{l}$ DNA, $1 \mu \mathrm{l}$ of each primer $(10 \mu \mathrm{l})$, Nuclease Free Water $(9.5 \mu \mathrm{l})$, in a final volume of $25 \mu \mathrm{l}$. Amplification steps were performedin a thermocycler Eppendorf Mastercycler pro $\mathrm{S}$ by incubation at $95^{\circ} \mathrm{C}$ for $2 \mathrm{~min}$, followed by 35 cyclesof denaturation at $95^{\circ} \mathrm{C}$ for $30 \mathrm{~s}$, annealing at $54^{\circ} \mathrm{C}$ for $30 \mathrm{~s}$, extension at $72^{\circ} \mathrm{C}$ for $90 \mathrm{~s}$, and a single final extension step at $72^{\circ} \mathrm{C}$ for 5 min (RUGINESCU \& al [17]). The PCR products were purified using the QIAquick PCR purification kit. Then, they were sequenced by the commercial company - CeMIA SA (Greece). The sequences obtained were compared with those from the public databases using NCBI BLAST (http://blast.ncbi.nlm.nih. gov/Blast.cgi).

\section{Results and Discussions}

Letea saline lake is located near the oldest nature reserve in Romania, the Letea forest reservation (Fig. 1). It is a permanent lake, surrounded by fresh water and without aquatic vegetation cover. During the studies, from October 2016 to May 2018, the pH values of the investigated samples were around 8.7-10.4, the water temperature was between 5.2 and $27.5^{\circ} \mathrm{C}$ and the chloride content was between 8.9-38.3 $\mathrm{g} \mathrm{L}^{-1}$ (LUCACI \& al [13]).
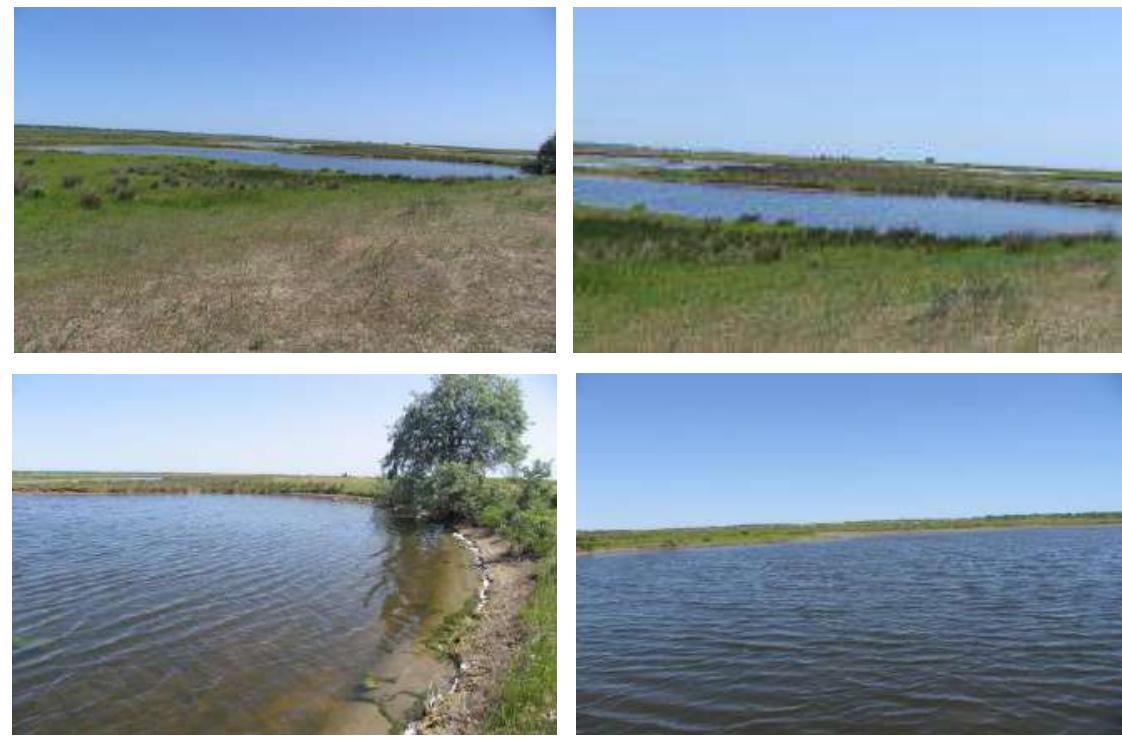

Figure 1. Letea saline lake, Danube Delta, Romania.

In the present study, the tested bacterial isolates were previously obtained by LUCACI \& al [13] from several water and sediment samples. Bacteria obtained from several water samples amounted to 72 isolates. Only ten bacterial colonies were isolated from sediments. Primary morphological identification established that 51 were Gram-negative bacteria and 31 were Gram-positive bacteria, both rods and cocci (LUCACI \& al [13]).

From the 82 isolates, 70 were oxidase-positive and 43 were catalase-positive; 35 bacteria were able to produce both catalase and oxidase (Fig. 2).
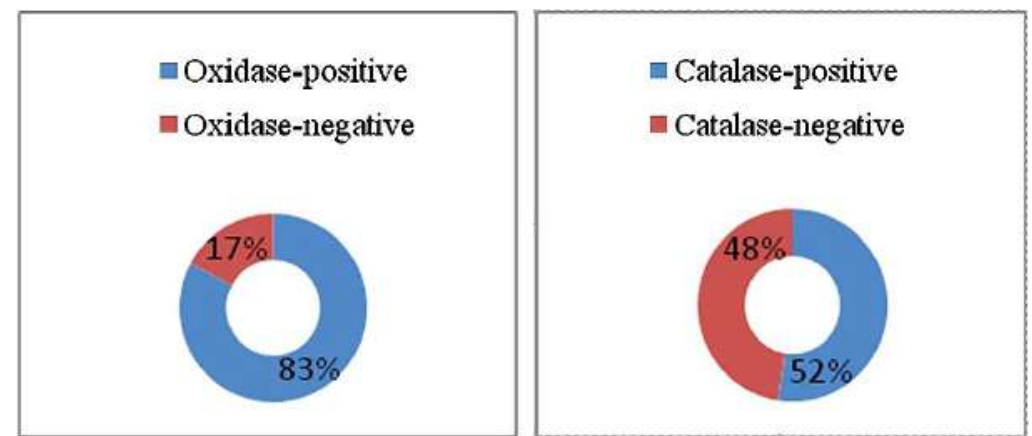

Figure 2. Biochemical tests of bacterial isolates. 
Isolated bacterial colonies were tested for their abilities to grow on different $\mathrm{NaCl}$ concentrations of the medium. The data in Figure 3 show that 69 isolates were halotolerant bacteria and 13 isolates were moderate halophilic (nine isolates were obtained from the water column and four isolates from the sediment). The highest number of moderately halophilic bacteria isolated from the water column and the sediment was in October 2017, when the $\mathrm{pH}$ value of the water was around 10 and the chloride content around $38 \mathrm{mg} \mathrm{L}^{-1}$. Nine isolates grew at $4 \mathrm{M} \mathrm{NaCl}$ concentration and these were isolated only in the spring (2017 and 2018).

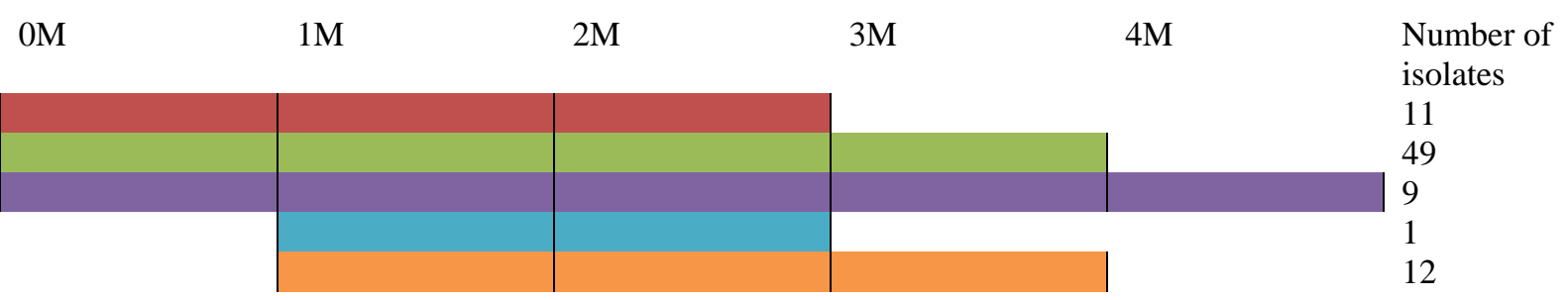

Figure 3. Salinity influence onisolates growth on $\mathrm{MH}$ culture medium with different $\mathrm{NaCl}$ concentrations (0M, 1M, 2M, 3M, 4M).

As observed (personal data), the halophilic and halotolerant bacteria isolated form Letea saline Lake had optimal growth below $10 \% \mathrm{NaCl}$. On the contrary, the halophilic bacteria isolated by JONES \& al [11] and SANCHEZ-PORRO \& al [18] from different hypersaline environments (e.g., Little Magadi and Natron, from
Southern Spain), grew optimally at $30 \%$, and $5-15 \%$ $\mathrm{NaCl}$, respectively.

The bacterial isolates were tested onsolid $\mathrm{MH}$ medium to produce different extracellular hydrolytic enzymes at different salinities, following previous descriptions in the literature (Fig. 4) (SANCHEZ-PORRO \& al [18]).

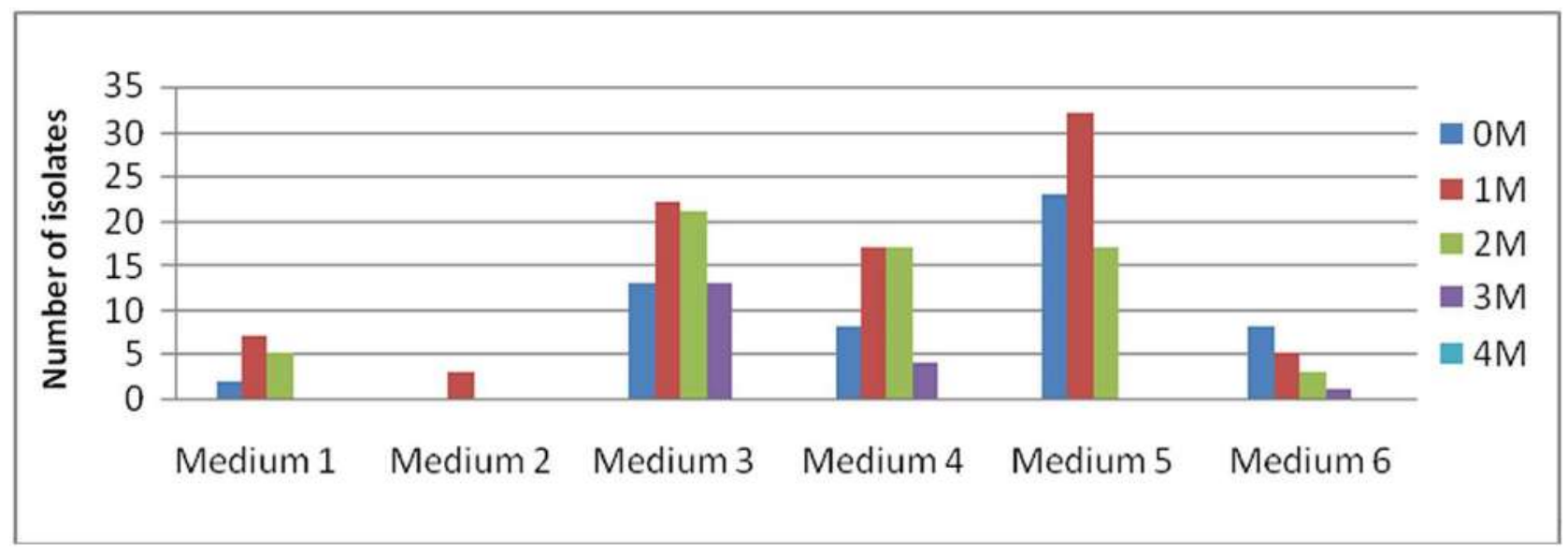

Figure 4. The capacity of isolates to hydrolyze different substrates: starch (medium 1), tributyrin (medium 2), inulin (medium 3), Tween 80 (medium 4), casein (medium 5), and carboxymethyl cellulose (medium 6), in $\mathrm{MH}$ culture medium with $0 \mathrm{M}, 1 \mathrm{M}, 2 \mathrm{M}, 3 \mathrm{M}$, and $4 \mathrm{M} \mathrm{NaCl}$.

The results obtained revealed that the tested isolates hydrolyzed the substrates in order: starch $(7)<$ carboxymethyl cellulose $(9)<$ Tween $80(18)<$ inulin $(26)<$ casein (35). Seven isolates had combined hydrolytic activities. None of the isolates had the ability to degrade gelatin. Interesting is the fact that in September 2016 and May 2018 , the isolated strains did not present the capacity to degrade starch and tributyrin. In May 2018, isolates did not show the capacity to degrade inulin and Tween 80 . From successive passages, most of all lose their capacity to produce several extracellular hydrolases. Sanchez-Porro et al. carried out studies on the hydrolytic activity of halophilic bacteria isolated from Spanish salterns to have hydrolytic activity. They tested the production of five hydrolases (DNase, protease, lipase, amylase, pullulanase). Most isolates produced amylase. The pullulanase was produced by isolates of Salinivibrio, Halomonas, Bacillus, and Salibacillus genera. Also, four isolates had the capacity to produce all five tested enzymes (SANCHEZPORRO \& al [18]). Of the 82 isolates, the predominant extracellular hydrolytic activities were recorded for lipase, caseinase, and inulinase. Similarly, Rohban et al [16] showed that moderate halophilic bacteria isolated from a hypersaline lake from Iran produce lipases, cellulases, amylases and pectinases. 
Depending on the intensity of hydrolytic activity, eight isolates (i.e., CNL1-9, C1L1-2, C1L1-4, C1L1-6, C1L1-9, C1L3-9, C2L1-1, C2L2-5) were selected for further analysis: one from October 2016, five from April 2017, and two from July 2017. All selected isolates were halotolerant (Table 1).

Table 1. The influence of salinity on the growth of selected isolates

\begin{tabular}{llllll}
\hline Isolates & \multicolumn{5}{c}{ MH medium supplemented with different concentrations of NaCl } \\
\hline & OM & 1M & 2M & 3M & 4M \\
\hline CNL1-9 & + & +++ & ++ & ++ & - \\
C1L1-2 & + +- & ++++ & +++ & ++ & - \\
C1L1-4 & ++++ & ++++ & +++ & + & $+/-$ \\
C1L1-6 & + +- & ++ & $+/$ & - & - \\
C1L1-9 & ++++ & +++ & ++ & $+/-$ & - \\
C1L3-9 & ++++ & +++ & ++ & $+/-$ & - \\
C2L1-1 & +++ & +++ & ++++ & - & - \\
C2L2-5 & ++++ & ++++ & +++ & - & - \\
\hline
\end{tabular}

Legend: (+: little growth; ++++: strong growth; +/-: very slight growth)

Four isolates (C1L1-2, C1L1-4, C2L1-1, and C2L2-5) exhibited the capacity to produce two different extracellular enzymes and one (C1L1-9) showed the ability to hydrolyze casein, carboxymethyl cellulose, and Tween 80 . Halophilic bacteria with combined hydrolytic activities can be attractive in the various biotechnological processes (RASOOLI \& al [15]).
Table 2 described the microbiological and biochemical characterization of the selected strains. Only one isolate was able to produce both oxidase and catalase.

These eight isolates were identified using by $16 \mathrm{~S}$ rRNA gene sequencing. Figure 5 shows the presence of approximately $1.5 \mathrm{~kb}$ amplicons, obtained through the PCR technique, corresponding to the $16 \mathrm{~S}$ rRNA genes.

Table 2. Phenotypical and biochemical characteristics of selected isolates

\begin{tabular}{lccccccccc}
\hline $\begin{array}{c}\text { Characterization } \\
\text { of isolates }\end{array}$ & CNL1-9 & C1L1-2 & C1L1-4 & C1L1-6 & C1L1-9 & C1L3-9 & C2L1-1 & C2L2-5 \\
\hline $\begin{array}{l}\text { Colony } \\
\text { morphology }\end{array}$ & Circular & Circular & Circular & Circular & Circular & Circular & Circular & Circular \\
Colony & Convex & Convex & Flat & Convex & Convex & Convex & Convex & Convex \\
Pigmentation & Pink & Cream & Pink & Cream & Cream & White & Cream & Cream \\
Gram staining & - & + & + & - & + & - & - & - \\
Catalase & - & - & + & - & + & - & - & - \\
Oxidase & + & - & + & + & - & + & + & + \\
\hline
\end{tabular}

Legend: (- : negative; +: positive)

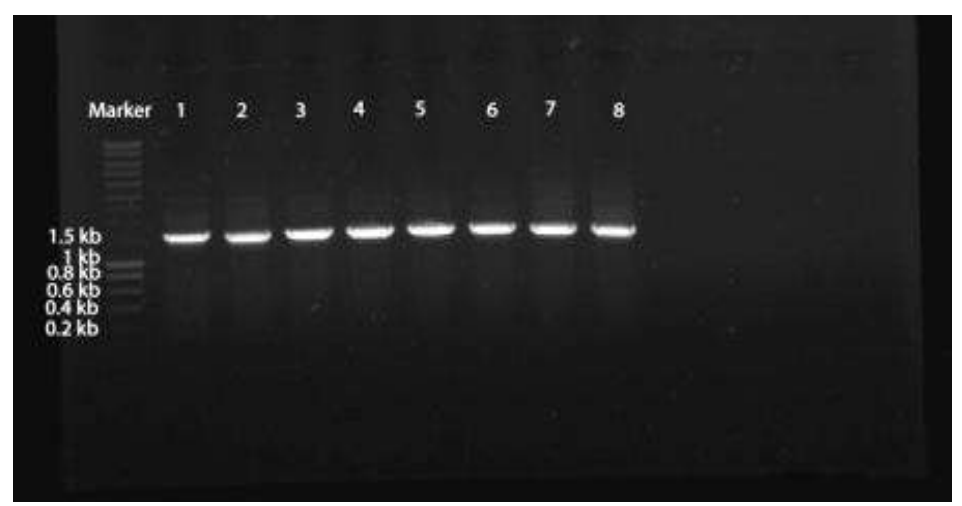

Figure 5. Agarose gel electrophoresis of PCR amplicons of $16 \mathrm{~S}$ rRNA gene fragments, from studied isolates (1-C1L1-4, 2-C1L1-9, 3-C1L1-6, 4-CNL1-9, 5-C2L2-5, 6-C1L1-2, 7-C2L1-1, 8-C1L3-9). 
The data in Table 3 shows the similarity of the isolates with other bacterial strains from the the public databases.
The closest phylogenic neighbor, with the corresponding GenBank accession numbers, is mentioned for each isolate (Figure 6).

Table 3. Taxonomic affiliation of the eight isolates based on the similarity of 16S r RNA gene sequence from saline Lake Letea

\begin{tabular}{lll}
\hline Isolates & Closest isolates name (GenBank accession number) & Similarity(\%) \\
\hline CNL1-9 & Marinobacter sp. ME108 (AJ302707.1) & $\mathbf{9 9}$ \\
C1L1-2 & Halobacillus sp. 4TMC2 (MK251570.1) & $\mathbf{9 9}$ \\
C1L1-4 & Virgibacillus sp.Bac332 (CP033046.1) & $\mathbf{9 8}$ \\
C1L1-6 & Marinobacter sp. M71 (FM992844.1) & $\mathbf{9 9}$ \\
C1L1-9 & Bacillus zhangzhouensis c9 (MK696234.1) & $\mathbf{9 9}$ \\
C1L3-9 & Halomonas sp. ALS9(KU714727.1) & $\mathbf{9 8}$ \\
C2L1-1 & Salinivibrio sp. JSM 114060 (JX220752.1) & $\mathbf{9 8}$ \\
C2L2-5 & Salinivibrio proteolyticus AB116 (KY646049.1) & $\mathbf{9 8}$ \\
\hline
\end{tabular}

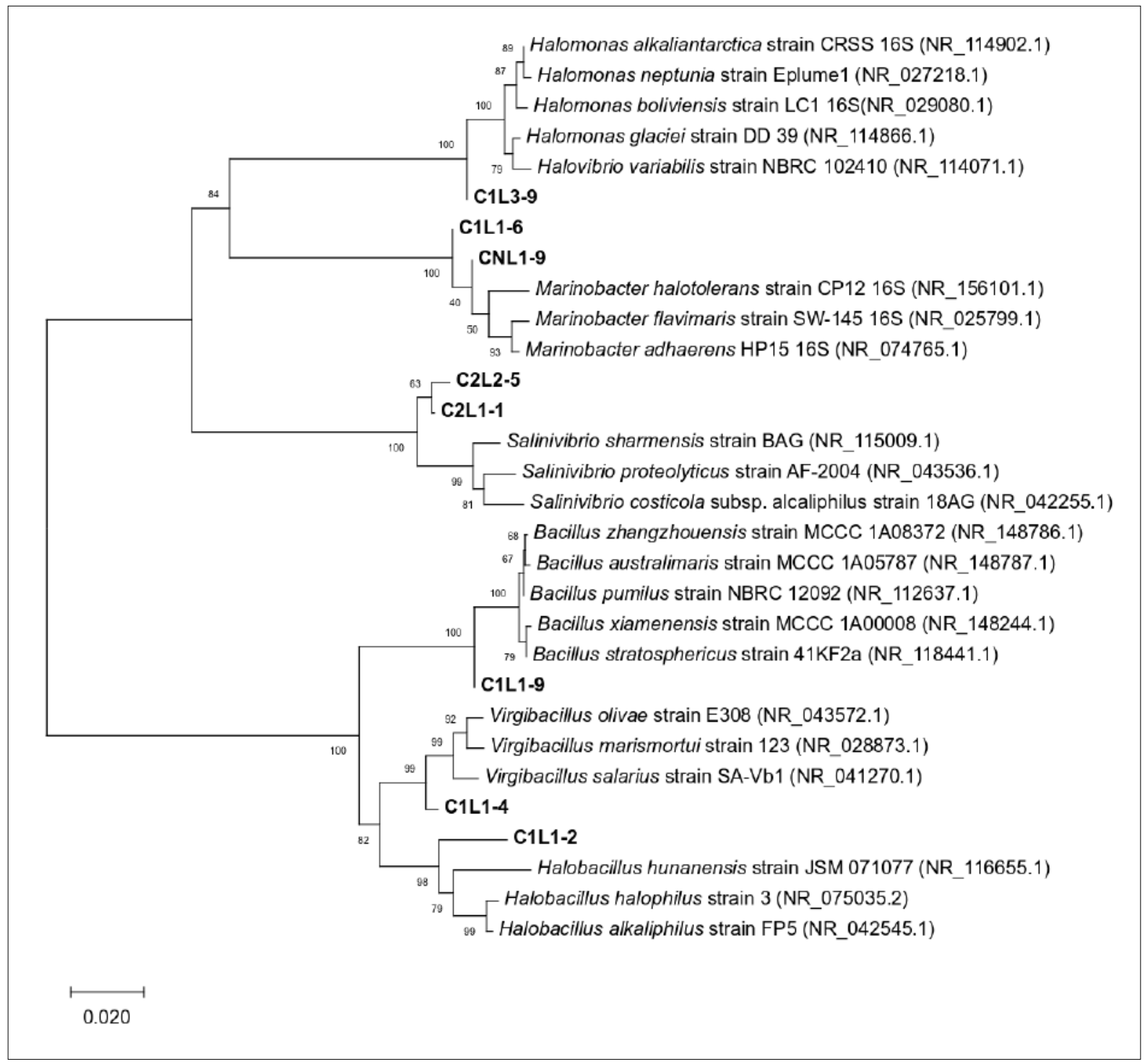

Figure 6. Phylogenetic position of the eight selected isolates. 
The isolates were identified as members of the genera: Marinobacter, Halobacillus, Virgibacillus, Bacillus, Halomonas and Salinivibrio.

\section{Conclusion}

The benefits of the one of first microbiological studies of this saline lake appear to be the isolation of 82 bacterial isolates from which 69 isolates were halotolerant and 13 isolates were moderate halophilic bacteria. The isolated strains were able to hydrolyze the substrates with starch, carboxymethyl cellulose, Tween 80 , inulin, casein. None of the isolates had the ability to degrade gelatin. Seven isolates had combined hydrolytic activities. Based on the intensity of hydrolytic activity, 8 strains with biotechnological potential use have been selected.

\section{Acknowledgments}

This work was supported byproject No RO1567IBB05/2016-2018 of the Institute of Biology Bucharest of the Romanian Academy. The research was conducted with the approval of the Administration of the Danube Delta Biosphere Reservation No 11/2016, 4/2017 and 1/2018.

\section{Conflict of Interest}

The authors have no conflict of interest to declare.

\section{References}

1. M. AZHAR, V. UNIYAL, N. CHAUHAN, D.S. RAWA. Isolation and biochemical characterisation of halophiles from the Sahastradhara region, Dehradun, India, International J ournal Current Microbiology and Applied Sciences, 3(12), 753-760 (2014).

2. H. BABAVALIAN, M.A. AMOOZEGAR, S. ZAHRAEI, R. ROHBAN, F. SHAKERI, M.M. MOGHADDAM. Comparison of bacterial biodiversity and enzyme production in three hypersaline lakes; Urmia, Howz-Soltan and Aran- Bidgol, Indian Journal Microbiology, 54, 444-449 (2014).

3. R. COJOC, S. MERCIU, G. POPESCU, L. DUMITRU, M. KAMEKURA, M. ENACHE. Extracellular hydrolytic enzymes of halophilic bacteria isolated from a subterranean rock salt crystal, Romanian Biotechnological Letters, 14(5), 4658-4664 (2009).

4. M. ENACHE, M. KAMEKURA. Hydrolytic enzymes of halophilic microorganisms and their economic value, Romaninan Journal of Biochemistry, 47(1), 47-59 (2010).

5. M.J. FOTI, D. YU, SOROKIN, E.E. ZACHAROVA, N.V. PIMENOV, J.G. KUENEN, G. MUYZ. Bacterial diversity and activity along a salinity gradient in soda lakes of the Kulunda Steppe (Altai, Russia), Extremophiles, 12, 133-145 (2008).

6. W.D. GRANT, B.E. JONES. Bacteria, Archaea and Viruses of Soda Lakes, M. SCHAGERL, eds., Soda Lake of East Africa. Springer International Publishing, Switzerland, 2016, pp. 97-147.
7. W.D. GRANT, D.Y. SOROKIN. Distribution and Diversity of Soda Lake Alkaliphiles, K. HORIKOSHI, eds., Extremophiles Hanbook, Springer, Tokyo, 2011, pp. 27-54.

8. W.D. GRANT, W.E. MWATHA, B.E. JONES. Alkaliphilis: ecology, diversity and applications, FEMS Microbiology Reviews, 75, 255-270 (1990).

9. D. HALDER, P. DUTTA, A. MONDAL, M. BASU. Isolation and characterization of halophilic bacteria from Sundarban Soil, International Journal of LifeScience Scientific Research, 2(4), 442-450 (2016).

10. K. HORIKOSHI. Alkaliphiles- from an industrial point of views, FEMS Microbiology Reviews, 18, 259-270 (1996).

11. B.E. JONES, W.D. GRANT, A. DUCKWORTH, G.C. OWENSON. Microbial diversity of soda lakes, Extremophiles, 2, 191-200 (1998).

12. S. KUMAR, R. KARAN, S. KAPOOR, S.P. SINGH, S.K. KHARE. Screening and isolation of halophilic bacteria producing industrially important enzymes, Brazilian Journal of Microbiology, 43(4), 1595-1603 (2012).

13. A.I. LUCACI, M. MOLDOVEANU, L. FLORESCU, R. COJOC, S. NEAGU, R. RUGINESCU, M. ENACHE. The seasonal dynamics of the cultivable microbial communities in Letea saline lake, Agro Life Scientific Journal, 8(1), 160-166 (2019).

14. R. MARGESIN, F. SCHINNER. Potential of halotolerant and halophilic microorganisms for biotechnology, Extremophiles, 5: 73-83 (2001).

15. M. RASOOLI, M.A. AMOOZEGAR, A.A. SEPAHY, H. BABAVALIAN, H. TEBYANIAN. Isolation, identification and extracellular enzymatic activity of culturable extremely halophilic Archaea and Bacteria of Inche Boroun Wetland, International Letters of Natural Sciences, 56, 40-51 (2016).

16. R. ROHBAN, M.A. AMOOZEGAR, A. VENTOSA. Screening and isolation of halophilic bacteria producing extracellular hydrolyses from Howz Soltan Lake, Iran, Journal of Industrial Microbiology and Biotechnology, 36, 333-340 (2009).

17. R.M. RUGINESCU, R. COJOC, M. ENACHE, V. LAZĂR. Preliminary Characterization of a Cellulase Producing Bacterial Strain Isolated from a Romanian Hypersaline Lake, Journal of Environmental Protection, 9, 1066-1081(2018).

18. C. SANCHEZ-PORRO, S. MARTIN, E. MELLADO, A. VENTOSA. Diversity of moderately halophilic bacteria producing extracellular hydrolytic enzymes, Journal of Applied Microbiology, 94, 295-300 (2003).

19. VENTOSA, M.T. GARCIA, M. KAMEKURA, H. OONISHI, F. RUIZ-BERRAQUERO. Bacillus halophilus sp. nov., a moderately halophilic Bacillus species, Systematic and Applied Microbiology, 12, 162-166 (1989).

20. J. YIN, J.-C. CHEN, Q. WU, G.-Q. CHEN. Halophiles, coming stars for industrial biotechnology, Biotechnol Advances, 33 (7), 1433-1442 (2014). 